\title{
Trade Structure, Trade Mode And the Urban-RURAL INCOME GAP IN CHINA
}

\author{
Hao Wei, Hongbing Li \& Ye Guo
}

School of Economics and Business Administration, Beijing Normal University, CHINA

Accepted: January 2013

\begin{abstract}
This paper analyses the effect of foreign trade in China on the urban-rural income gap from certain angles including trade scale, trade structure and trade mode at the national and provincial levels. The empirical results indicate that, from the perspective of trade scale, the export and import in the eastern and national regions have an expansion effect on the urban-rural income gap, and, in the central regions, they have a reduction effect. Furthermore, export in the western regions has a reduction effect while import in these regions did not have a significant effect. From the perspective of trade structure, the trade of high-tech products and labour-intensive products in the national and eastern regions has an expansion effect, and the trade of the above-mentioned products in the central regions has a reduction effect. The trade of labour-intensive products in the western regions has a reduction effect, and that of high-tech products an expansion effect. From the perspective of trade mode, processing trade and general trade in the national and eastern regions have an expansion effect, while in the central regions they have a reduction effect. General trade in the western regions would expand the urban-rural income gap, and processing trade does not have a significant effect. Consequently, when the South African Government is working out trade multiplicative and corresponding policy, they should consider the development of foreign trade and should pay attention to the labour market structure.
\end{abstract}

Key words: trade scale, trade structure, trade mode, urban-rural income gap, labour market structure

JEL: F16, J21

\section{1}

\section{Introduction}

Since the 1970s, international trade has rapidly been developed, and problems like income disparity, of which the core problem is income gap expansion, are increasing, attracting widespread attention from international as well as labour economists (Harrison, Mclaren \& Margaret, 2010). Scholars have researched this problem at two levels. On the one hand, research on the gap of trade benefits at national level has been done; and, at the same time research was done on the income gap of various groups and regions. From the perspective of the income gap, most literature recognises that there is an internal relation between foreign trade and the income gap. Haskel and Slaughter (2001) conducted empirical research on these aspects in England; While Bernard and Jensen (1997), and Ebenstein, Harrison, Margaret \& Shannon (2009) conducted empirical research related to America. There are also some scholars who conducted this research on developing countries, like Mexico (Harrison \& Hanson, 1999); Chile (Beyer, Rojas \& Vergara, 1999); Columbia (Goldberg \& Pavcnik, 2007) and the Phillipines (Hasan \& Jandoc, 2010). Research on foreign trade for both developing and developed countries indicates that foreign trade has had an effect on the income gap, from the perspective of industry, region and the individual.

In China, foreign trade and the urban-rural income gap are developing an era of reform and greater foreign exposure. The policies of reform, especially, relate to internal reform and greater exposure to the outside world. Domestically, migrant rural labourers are the result of internal reform, while internationally China has implemented an export-oriented economy, which includes attracting foreign capital and vigorously developing processing trade. Foreign trade promotes economic 
development and reform due to greater foreign exposure. The conflict of these two approaches causes tension. Along with the development of reform and foreign exposure, the scale of migrant rural labourers expanded exponentially. The 2 million migrant rural labourers in 1983, increased to 30 million in 1989. These grew to 62 million labourers in 1993, and 75.5 million in 2000. BY 2001 the number had further grown to 83.99 million, and by 2002 this number had reached more than 100 million. Migrant rural labourers in China have kept increasing ever since and by 2006, there were 132 million migrant rural labourers (Cai $\&$ Wang, 2009). The huge transfer of labour not only reduces surplus rural labour, but also increases the income of rural residents. Furthermore, labour transfer also provides cheap labour resources for economic development and foreign trade development, especially the development of introductory industrial and processing trades. Both statistical data and the current situation indicate that foreign trade development and migrant rural labourers are interactive. Through the size of employment quantity, the biased effect of employment quality and the pulling-up effect of labour productivity, the foreign trade effect of rural labour, and its income, is increased. Foreign trade impacts the urban-rural income gap by affecting the employment of diverse groups in a similar way. Consequently, we must consider the factors of foreign trade when conducting research on the urban-rural income gap.

From the perspective of trade scale, trade mode and trade structure, this paper employs panel data from 29 provinces spanning 1986-2010 to analyse the effect of foreign trade on the urban-rural income gap, which has attracted increasing international attention. This paper provides informative evidence of China, and it makes a significant attempt, from the perspective of foreign trade, to analyse the causes of the expanding urban-rural income gap and its solutions.

This article consists of five parts. Section 1 is the introduction to the study; section 2 is a Literature review of foreign trade and the urban-rural income gap; section 3 provides the econometric model, design index and discusses the data; section 4 provides the empirical and results analysis; and section 5 concludes and provides policy suggestions.

\section{2}

\section{Literature review}

The Heckscher-Ohlin factor endowment theorem (H-O theorem) and Stolper-Samuelson Theorem (S-S theorem) are often quoted in research on the relationship between foreign trade and the income gap. According to earlier research, because of the effect of income from production factors, foreign trade has improved the income level of unskilled labourers in developing countries, which had advantages pertaining to labour endowment, thereby narrowing the income gap (Deardorff, 1982; Bhagwati \& Srinivasan, 2002; Bhagwati, 2004). Regrettably, this theory was not supported by evidence from developing countries, particularly India (Kumar \& Mishra, 2008), the Philippines (Hasan \& Jandoc, 2010), and 17 countries in Latin America (Perry \& Olarreaga, 2006). In those countries, the income gap was expanding instead of narrowing, during the greater foreign exposure era.

The discrepancy between theory and practice attracted the attention of many scholars.Many scholars have conducted empirical research on different countries and regions. Amiti and Davis (2008), and Amiti and Cameron (2012) used data from Indonesian manufacturing enterprises from 1991 to 2000 to analyse the effect of tariff cuts on wages, and found that tariff cuts reduce wages in import-competing sectors and elevate wages in export sectors. From the perspective of technology progress and export destination, Bustos (2007) used panel data from Argentine enterprises from 1992 to 1996 and Brambilla, Lederman \& Porto (2010) used data from 1991 to 2000 to analyse whether the heterogeneity of technical levels and wage gaps in export destinations affect wage income, and consequently, expand the income gap between high-skilled and low-skilled workers. Hummels, Jorgensen, Munch \& Xiang (2010) used firm-level data from the labour force and trade to determine whether the exogenous block of trade and offshore outsourcing on enterprise and wage level are different. Import shocks increase the wages of skilled workers and decrease those of unskilled workers and, consequently, expand the income 
gap. Export shocks increase the wages of both types of workers, but the wage increase of low-skilled workers and middle- skilled workers is more pronounced. Wei and Liu (2011) used data from 125 countries to analyse the effects of international trade on various countries as well as the wage income in different types of countries. They found that trade factors are important factors that affect the income inequality in Asian developing countries. Import is in favour of narrowing the income gap, and export results in an expanding income gap. Compared with the results from other developing countries, the effects of import and export trade in Asian developing countries are greater and more significant.

A great deal of research on China has been conducted. Wei and Wu (2001) used data from 1988 to 1993 to conduct research on China, and they arrived at the conclusion that foreign trade contributes to the narrowing of the urban-rural income gap. However, scholars' post-studies claim that foreign trade has expanded the urban-rural income gap in China. According to research by Kanbur and Zhang (2005), from 1979 to 2000 foreign trade expanded the urban-rural income gap. Shen and Zhang (2011) found that the inverted U-shaped relationship between foreign trade and the urban-rural income gap is uncertain. An increase in foreign trade expanded the urban-rural income gap. Yuan, Wei \& Yang (2011) found the increase in foreign exposure and in finished products' trade proportion narrowed the urban-rural income gap. Wei and Zhao (2012) found international trade showed diverse outcomes on the employment and income of skilled and unskilled workers. The effect of international trade on employment in China is a biased effect of employment quality and employment expansion. Furthermore, Wan $\mathrm{Lu}$ and Chen (2007) demonstrated that from 1987 to 2001 the effect of foreign trade on the regional income gap in China is significantly positive, and has strengthened over time. Wei (2009) found that the export gap has a durable and significantly positive effect on the regional income gap, and makes the greatest contribution to the income gap. Han, Liu \& Zhang (2012) found that the regional wage gap expanded significantly after joining the WTO.
On the whole, a great deal of research has been conducted on the effect of international trade on the domestic income gap and changes in wages, but little research has been conducted on the effect of international trade on the urban-rural income gap, and the results of this research are conflicting. Furthermore, previous research conducted from the perspective of trade scale, shows a lack of analysis from the perspective of trade by trade structure and trade mode.

Based on the latter, this paper makes use of panel data from 29 provinces from 1986 to 2000 to empirically analyse the effect of international trade and the urban-rural income gap. There are several key contributions in this paper. Firstly, this paper considers the ratio of urban to rural income and the Theil Index as indicators measuring the urban-rural income gap, and conducts a comparative study. Secondly, goods are divided into high-tech and labour-intensive products, and this paper analyses the effects of the trade of various products on the urban-rural income gap. This paper also analyses the effects of general trade and processing trade on the urban-rural income gap. Thirdly, this paper analyses the effects of certain trade structures and trade modes on the regional urban-rural income gap, and proposes policies for the transformation of the development model of foreign trade.

\section{3}

\section{Model, variables and data}

\subsection{Setup of econometric model and variable declaration}

Based on research by Wei et al. (2001), Wan et al. (2007) and Han et al. (2012), combining the reality of foreign trade and the urban-rural income gap in China, this paper implements the urban-rural income gap as explained variable and trade factor as explanatory variable. This paper also makes use of seven non-trade factors that may affect the urban-rural income gap as control variables, and consequently, the econometric model is set out as follows: 


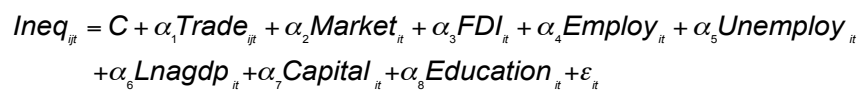

In this model, Ineq $q_{i j t}$ represents the urban-rural income gap, and $i, j$ and $t$ represent province, various measures of indicator, and year, respectively. $\alpha_{I} \sim \alpha_{8}$ represents the coefficient of explanatory variables, measuring the marginal effect of explanatory variables on the urbanrural income gap. $C$ and $\varepsilon$ represent the intercept term and random disturbance term, respectively. According to equation (1), the specification and measure of indicators are as follows.

\subsubsection{Explained variable}

The explained variable of this paper is the urban-rural income gap (Ineq) and is measured by means of two methods;

1) The ratio of urban to rural income (Income), suggests measuring the urbanrural income gap by means of the ratio of

$$
\text { Theil }_{i, t}=\frac{P_{i, t}^{u}}{P_{i, t}} \ln \left(\frac{P_{i, t}^{u}}{P_{i, t}} / \frac{Z_{i, t}^{u}}{Z_{i, t}}\right)+\frac{P_{i, t}^{c}}{P_{i, t}} \ln \left(\frac{P_{i, t}^{c}}{P_{i, t}} / \frac{Z_{i, t}^{c}}{Z_{i, t}}\right)
$$

where $\mathrm{u}$ and $\mathrm{c}$ represent urban areas and rural areas, respectively; $P_{i}^{u}$ and $P_{i}^{c}$ represent the overall income level (represented by product of population and per capita income) of urban and rural areas in region $i$, respectively. $P_{i}$ represents the overall income in region $i$. $Z_{I}^{i}$ and $Z_{\mathrm{i}}^{C}$ represent urban and rural population size in region $i$, respectively. $Z_{i}$ represents total population in region $i$.

\subsubsection{Explanatory variable}

\section{a) Trade factor (Trade)}

This paper measures the trade factor on three levels, namely trade openness, trade structure and trade mode. Trade openness includes openness of trade (Trade), openness of export (Export) and openness of import (Import). The three indicators are measured by the ratio of total volume of trade, export volume, and import volume to regional GDP in the same year, and volume of trade, export volume and import volume are converted by the central parity of dollar to RMB in the same year. Trade structure includes the trade of high-tech products (Tectrade) and the trade of labour- urban residents' per capita disposable income to rural residents' per capita disposable income (Lu \& Chen, 2004; Yuan et al., 2011; Wei \& Zhao, 2012).

2) Theil Index (Theil). The Theil Index is widely used in research on the urban-rural income gap. This paper uses the Theil Index to measure China's urban-rural income gap, and the ratio of urban to rural income is considered a comparative study.

Wang et al. (2007) made a meaningful attempt to calculate the Theil Index, and measured the urban-rural income gap in various regions and certain periods by calculating the Theil Index of $i$ cross-sections and $t$ periods. Drawing from this calculation, and combining it with research by Shorrocks (1980), this paper calculates the Theil $_{i, t}$ formula as follows:

intensive products (Labtrade). The total volume of trade minus the trade volume of high-tech products is regarded as the trade volume of labour-intensive products. The trade volumes of high-tech products and labour-intensive products are taken as the logarithm after being converted by the central parity of dollar to RMB in the same year. Trade mode include general trade and processing trade, and they are measured by means of the volume of general trade and the volume of processing trade, which are taken as the logarithm after being converted by the central parity of dollar to RMB in the same year.

\section{b) Other non-trade factors}

Degree of denationalisation (Private). This indicator represents the degree of the government's regulation and is measured by means of the ratio of workers in non-state owned enterprises to total workers in each province.

Openness to foreign direct investment (FDI). FDI affects the income gap of the host country by wage premiums and potential technology spillover. It is measured by means 
of the ratio of utilised foreign capital to GDP in each province.

Employment structure (Employ). The inflow of surplus rural labour changes the employment structure and influences the income level of labourers in both urban and rural areas. It is measured by means of the ratio of employment in the primary industry to total employment.

Urban unemployment rate (Unemploy). With the adjustment of the economic structure and the dualism of urban and rural employment, employment opportunity becomes an important factor impacting the income gap between various groups. it is measured by using the unemployment rate registered by provinces over the year.

Economic development (Lnagdp). It is generally acknowledged that developed areas aggregate more resources, provide more employment opportunities and higher wages, and consequently increase the income levels of the local residents. It is measured by means of the logarithm of the per capita GDP of the provinces.

Ratio of urban to rural in fixed-asset investment (Capital). For a long time, urbanbiased economic policy caused an inequality of fixed-asset investment between urban and rural areas, and the proportion of expenditure on agriculture to total financial expenditure is also declining, which may be an important factor that expands the urban-rural income gap ( $\mathrm{Lu} \&$ Chen, 2004). It is measured by means of the ratio of urban to rural fixed-asset investment.

Average level of education (Education). The urban-rural education gap is caused mainly by the urban-biased education policy, and the education gap is a significant factor affecting the urban-rural income gap (Chen et al., 2010). We measure the average level of education by means of the average years of schooling of persons who are six years and above.

\subsection{Data sources}

Considering that the data of Tibet is insufficient, and it has not been long since Chongqing became a municipality, these two provinces are left out. This paper selects panel data spanning 1986 to 2000 , from 29 provinces and cities, and they are divided into three areas, including the eastern, central and western areas. Empirical research is conducted on the relationship between foreign trade and the urban-rural income gap.

The urban-rural proportion and Theil Index used in this paper are calculated according to the raw data from the China Economy Information NET and the China Statistical Yearbook. Data pertaining to the total exportimport volume of provinces and foreign trade spanning 1986 to 1991 come from the China Statistics Compilation over 60 years. Data pertaining to foreign trade spanning 1992 to 2010 come from the China Statistical Yearbook, and are collected according to the location of the operating agency. Considering the availability of data and research priorities, this paper selects trade data from 2000 to 2010 pertaining to high-tech products and labourintensive products in provinces. The data are drawn from the websites of The Ministry of Commerce of the People's Republic of China (MOFCOM) and the State General Administration of Customs. Data pertaining to general trade and processing trade from 2000 to 2010 are selected for a future study, and data spanning 2001 to 2008 were acquired from CSMAR, and missing data as well as data of other years come from the Statistical Yearbook of provinces. Processing trade includes processing and assembling trade, feeding processing trade and outward processing.

The data pertaining to foreign direct investment used by provinces come from the China Statistical Yearbook and the Statistical Yearbook of provinces. The central parity rate of RMB and the dollar comes from the China Statistical Yearbook, 2010. The employment structure, degree of denationalisation, urban unemployment rate, economic development, and the ratio of urban fixed-asset investment to rural fixed-asset investment are calculated according to the China Statistics Compilation over 60 years and the China Statistical Yearbook. The average years of schooling of persons six years and older are calculated according to the China Statistical Yearbook and the China Population Statistics and Yearbook. 


\section{4}

\section{Empirical research and result analysis}

\subsection{Analyses from the perspective of trade openness: Regression at national level}

Considering the individualities and characteristics of the data, this paper uses a fixed effect method to estimate the model, and the Hausman Test also rejects the null hypothesis of random effect. Table 1 shows the regression results, which take Income and Theil as explanatory variables, and its goodness of fit is high. An adjusted goodness of fit is more than 0.86. It is demonstrated that there is a high correlation between the urban-rural income gap and trade openness (Trade), openness to export (Export) and openness to import (Import), and it is also demonstrated that foreign trade is an important factor affecting the urban-rural income gap in China.

\section{Table 1}

Regression results of ratio of urban income to rural income and Theil index: 1986 to 2000

\begin{tabular}{|c|c|c|c|c|c|c|}
\hline & \multicolumn{3}{|c|}{ Ratio of urban income to rural income } & \multicolumn{3}{|c|}{ Theil Index } \\
\hline & & $\begin{array}{l}\text { Openness } \\
\text { to export }\end{array}$ & $\begin{array}{l}\text { Openness } \\
\text { to import }\end{array}$ & $\begin{array}{c}\text { Trade } \\
\text { openness }\end{array}$ & $\begin{array}{l}\text { Openness } \\
\text { to export }\end{array}$ & $\begin{array}{c}\text { Openness to } \\
\text { import }\end{array}$ \\
\hline \multirow{2}{*}{ C } & $7.9093^{* * * *}$ & $7.2581^{* * *}$ & $7.6275^{\text {*** }}$ & $0.6501^{* * *}$ & $0.6229^{* * *}$ & $0.6327^{* * * *}$ \\
\hline & $(12.36)$ & $(11.08)$ & $(11.86)$ & $(11.27)$ & $(10.83)$ & $(10.98)$ \\
\hline \multirow{2}{*}{ Trade } & $0.6413^{* * * *}$ & & & $0.0314^{* * *}$ & & \\
\hline & $(11.72)$ & & & $(6.37)$ & & \\
\hline \multirow{2}{*}{ Export } & & $1.0948^{\text {*** }}$ & & & $0.0573^{* * *}$ & \\
\hline & & $(9.12)$ & & & $(5.44)$ & \\
\hline \multirow{2}{*}{ Import } & & & $0.9182^{\text {**** }}$ & & & $0.0431^{\text {**** }}$ \\
\hline & & & $(10.92)$ & & & $(5.72)$ \\
\hline \multirow{2}{*}{ Private } & $-1.0235^{* * * *}$ & $-0.8376^{* * *}$ & $-0.9773^{\text {*a*t }}$ & $-0.1586^{* * *}$ & $-0.1505^{* * *}$ & $-0.1554^{* * * *}$ \\
\hline & $(-4.92)$ & $(-3.92)$ & $(-4.65)$ & $(-8.45)$ & $(-8.02)$ & $(-8.25)$ \\
\hline \multirow{2}{*}{ FDI } & $-3.6145^{* \star *}$ & $-3.3540^{\star \star * *}$ & $-2.9913^{* * * *}$ & $-0.1675^{* * *}$ & $-0.1608^{* * *}$ & $-0.1340^{* \star * *}$ \\
\hline & $(-6.93)$ & $(-6.16)$ & $(-5.83)$ & $(-3.56)$ & $(-3.36)$ & $(-2.91)$ \\
\hline \multirow{2}{*}{ Employ } & $1.3888^{* * *}$ & $1.4369^{* * *}$ & $1.2580^{\text {**** }}$ & $0.1024^{* * *}$ & $0.1056^{* * *}$ & $0.0958^{* * * *}$ \\
\hline & $(6.29)$ & $(6.26)$ & $(5.65)$ & $(5.14)$ & $(5.24)$ & $(4.80)$ \\
\hline \multirow{2}{*}{ Unemploy } & -0.0082 & -0.0146 & -0.0041 & -0.0008 & -0.0011 & -0.0006 \\
\hline & $(-0.96)$ & $(-1.64)$ & $(-0.47)$ & $(-1.01)$ & $(-1.42)$ & $(-0.76)$ \\
\hline \multirow{2}{*}{ Lnagdp } & $-0.4216^{* * * *}$ & $-0.4111^{* * *}$ & $-0.3510^{\text {*t** }}$ & $-0.0313^{* * *}$ & $-0.0314^{* * *}$ & $-0.0276^{\text {*t** }}$ \\
\hline & $(-6.43)$ & $(-5.99)$ & $(-5.39)$ & $(-5.30)$ & $(-5.22)$ & $(-4.73)$ \\
\hline \multirow{2}{*}{ Capital } & $0.0166^{* * *}$ & $0.0211^{* * *}$ & $0.0126^{* * * *}$ & $0.0007^{* *}$ & $0.0009^{* * *}$ & 0.0005 \\
\hline & $(4.86)$ & $(5.88)$ & $(3.64)$ & $(2.16)$ & $(2.87)$ & (1.54) \\
\hline \multirow{2}{*}{ Education } & $-0.2231^{* \star *}$ & $-0.1692^{* * *}$ & $-0.2580^{* * *}$ & $-0.0279^{* * *}$ & $-0.0252^{* * *}$ & $-0.0295^{* * *}$ \\
\hline & $(-8.90)$ & $(-6.50)$ & $(-9.98)$ & $(-12.34)$ & $(-11.01)$ & $(-12.72)$ \\
\hline $\mathbf{R}^{2}$ & $0.79 ¥$ & 0.77 & 0.78 & 0.77 & 0.77 & 0.77 \\
\hline Adj- $R^{2}$ & 0.78 & 0.76 & 0.77 & 0.76 & 0.76 & 0.76 \\
\hline
\end{tabular}

Instructions: number in brackets is $t$-vale, and ***, ** * represent passing test at the 0.01, 0.05, 0.1 significance level, respectively.

Furthermore, from the perspective of openness to export and openness to import, their correlation coefficients are positive and pass the test at the 0.01 significance level. It is demonstrated that trade at national level is an important factor expanding the urban-rural income gap. Furthermore, the regression results, which consider the ratio of urban to rural income and the Theil Index as explanatory variables, show that the effect of export on the expanding urban-rural income gap in China, of which the coefficient is 1.0948 and 0.0573 , is more obvious than that of import, of which the coefficient is 0.9182 and 0.0431 . 
Consequently, it is demonstrated that export has a greater effect on the urban-rural income gap than import does.

Among the other explanatory variables, all of them show a significant correlation, except for the urban unemployment rate (Unemploy). The degree of denationalisation (Private) is significantly negative, which demonstrates that the higher the ratio of workers in nonstate-owned enterprises to total workers, the higher the degree of market development. Consequently, the convergence of wages is in favour of raising the income level of workers in non-state-owned enterprises. It is also in favour of narrowing the income gap between workers in different ownership enterprises, which is in accordance with the conclusions by Yang, Sylvie and Li (2011) and theoretical expectation. Economic development (Lnagdp) and average level of education (Education) have significantly negative correlations with income gap, and this demonstrates that the more developed an economy is, the more employment opportunities there will be. A higher average level of education is in favour of human capital accumulation, and consequently narrows the urban-rural income gap. Openness to trade (FDI) has a significantly negative correlation, which means that, along with the development of greater foreign exposure, the inflow of foreign trade significantly suspends the expanding trend of the income gap. Employment structure (Employ) and the ratio of urban to rural fixed-asset investment (Capital) have significantly positive correlations with the urban-rural income gap, which demonstrates that, if the proportion of workers in the primary industry is higher and the gap in urban-rural fixed-asset investment is wider, the income of rural residents will become less and the urban-rural income gap will expand.

\subsection{Analyses from the perspective of trade openness: Regression at regional level}

Tables 2 and 3 show the regression results making use of the ratio of urban income to rural income and the Theil Index as explained variables. The results demonstrate that trade is an important factor affecting the urban-rural income gap in the eastern areas, central areas and western areas; however, it has varying effects in different areas, and results with various explained variables are also different.

a) The correlation coefficients of trade openness, openness to export and openness to import in the eastern regions are significantly positive. When using the ratio of urban to rural income as explained variable, the regression results basically agree with the Theil Index as explained variable, which verifies the robustness of the regression results (lines 1-3 in tables 2 and 3). At the same time, trade significantly expands the urban-rural income gap in the eastern regions, and the effect of export is greater than that of import, which is in accordance with results at national level.

b) The correlation coefficients of trade openness, openness to export and import in the central regions are significantly negative, suggesting that foreign trade is in favour of narrowing the urban-rural income gap. Evidently, the regression results of the central regions vary from those of the western and eastern regions, and they differ from each other in two ways. On the one hand, the directions of influence are different. There are negative correlations between the three trade indicators and the urban-rural income gap measured by means of the ratio of urban to rural income, but they are not significant (lines 4-6 in Table 2). There are significantly positive correlations between the three trade indicators and the urban-rural income gap measured by means of the Theil Index (lines 4-6 in Table 3). The reasons for this occurance are that the two measurements have different focuses. On the other hand, the degree of the influence also varies, and the effect of import on the narrowing of the urban-rural income gap is greater than the effect of export.

c) In the western regions, openness to trade has a significantly negative correlation with the urban-rural income gap, but there is no significant correlation between openness to trade and the urban-rural income gap. Export can significantly narrow the urban-rural income gap, but the effect of 
import is not apparent. Comparing Table 2 with Table 3, it is demonstrated that the regression results of trade openness and openness to export are robust, while the regression result of openness to import is not robust.

Table 2

Regression results (1) of trade openness and the urban-rural income gap at regional level: 1986 to 2000

\begin{tabular}{|c|c|c|c|c|c|c|c|c|c|}
\hline \multicolumn{10}{|c|}{ Explained variable: Ratio of urban income to rural income } \\
\hline & \multicolumn{3}{|c|}{ Eastern regions } & \multicolumn{3}{|c|}{ Central regions } & \multicolumn{3}{|c|}{ Western regions } \\
\hline & (1) & (2) & (3) & (4) & (5) & (6) & (7) & (8) & (9) \\
\hline \multirow{2}{*}{ C } & $3.7418^{* * *}$ & $2.5163^{\text {*⿻*⿲二丨匕口 }}$ & $3.8999^{* * *}$ & -1.2261 & -1.1674 & -1.4056 & 1.0739 & 1.4920 & $2.0520^{*}$ \\
\hline & $(4.70)$ & $(3.29)$ & $(4.52)$ & $(-1.13)$ & $(-1.06)$ & $(-1.30)$ & $(0.94)$ & $(1.35)$ & $(1.74)$ \\
\hline \multirow{2}{*}{ Trade } & $0.3158^{* * *}$ & & & -0.6771 & & & $-2.0889^{* * *}$ & & \\
\hline & $(7.87)$ & & & $(-1.07)$ & & & $(-3.09)$ & & \\
\hline \multirow{2}{*}{ Export } & & $0.6403^{\text {**** }}$ & & & -0.6589 & & & $-2.6930^{\text {t*t* }}$ & \\
\hline & & $(8.29)$ & & & $(-0.67)$ & & & $(-3.47)$ & \\
\hline \multirow{2}{*}{ Import } & & & $0.3855^{* * *}$ & & & -1.2309 & & & -0.2325 \\
\hline & & & $(5.64)$ & & & $(-1.11)$ & & & $(-0.17)$ \\
\hline \multirow{2}{*}{ Private } & 0.0662 & 0.2423 & 0.1933 & $3.9175^{\cdots *}$ & $3.9414^{\text {w"* }}$ & $3.9305^{* * *}$ & -0.1732 & -0.1485 & 0.1977 \\
\hline & $(0.31)$ & $(1.19)$ & $(0.86)$ & $(6.70)$ & $(6.74)$ & $(6.74)$ & $(-0.44)$ & $(-0.38)$ & $(0.5050)$ \\
\hline \multirow{2}{*}{ FDI } & -0.2870 & -0.3932 & 0.2820 & $-8.9421^{* * *}$ & $-9.3778^{\text {**** }}$ & $-8.6319^{* * t *}$ & $-5.0726^{* *}$ & $-5.4481^{* *}$ & $-5.7534^{* *}$ \\
\hline & $(-0.64)$ & $(-0.88)$ & $(0.62)$ & $(-4.84)$ & $(-5.22)$ & $(-4.48)$ & $(-2.11)$ & $(-2.28)$ & $(-2.34)$ \\
\hline \multirow{2}{*}{ Employ } & $0.9293^{* * *}$ & $1.3042^{* * * *}$ & $0.6640^{* *}$ & $-1.2925^{* * *}$ & -1.3228 & $-1.2366^{* * * *}$ & 3.6446 & $3.4627^{* * * *}$ & $3.1548^{* * *}$ \\
\hline & (3.59) & $(4.98)$ & $(2.43)$ & $(-3.06)$ & $(-3.11)$ & $(-2.91)$ & $(8.67)$ & (8.7615) & $(7.35)$ \\
\hline \multirow{2}{*}{ Unemploy } & -0.0195 & $-0.0426^{\text {*t** }}$ & -0.0151 & 0.1116 "** & $0.1108^{\text {t*** }}$ & $0.1110^{* * * *}$ & -0.0088 & -0.0080 & -0.0123 \\
\hline & $(-1.39)$ & $(-3.14)$ & $(-0.99)$ & (3.54) & $(3.50)$ & $(3.52)$ & $(-0.88)$ & $(-0.80)$ & $(-1.21)$ \\
\hline \multirow{2}{*}{ Lnagdp } & $-0.1760^{* *}$ & -0.1349 & $-0.1729^{*}$ & 0.0942 & 0.0845 & 0.1050 & 0.1256 & 0.0947 & 0.0095 \\
\hline & $(-2.09)$ & $(-1.63)$ & $(-1.95)$ & $(0.75)$ & $(0.67)$ & $(0.83)$ & $(0.99)$ & $(0.78)$ & $(0.07)$ \\
\hline \multirow{2}{*}{ Capital } & $0.0149^{* * *}$ & $0.0174^{\text {t** }}$ & $0.0138^{\circ * * *}$ & 0.0160 & 0.0140 & 0.0165 & -0.0095 & -0.0093 & -0.0012 \\
\hline & $(4.19)$ & $(4.94)$ & $(3.65)$ & $(1.41)$ & $(1.26)$ & $(1.45)$ & $(-1.57)$ & $(-1.58)$ & $(-0.21)$ \\
\hline \multirow{2}{*}{ Education } & $-0.0616^{*}$ & 0.0196 & $-0.0818^{* *}$ & 0.0217 & 0.0238 & 0.0251 & $-0.0922^{* *}$ & $-0.1086^{* * * *}$ & -0.1296 \\
\hline & $(-1.94)$ & $(0.65)$ & $(-2.27)$ & $(0.35)$ & $(0.38)$ & $(0.40)$ & $(-2.23)$ & $(-2.74)$ & $(-3.05)$ \\
\hline R2 & 0.83 & 0.84 & 0.82 & 0.74 & 0.73 & 0.74 & 0.77 & 0.77 & 0.76 \\
\hline $\operatorname{Adj}-R^{2}$ & 0.82 & 0.83 & 0.80 & 0.71 & 0.71 & 0.71 & 0.75 & 0.75 & 0.74 \\
\hline
\end{tabular}

The regression results demonstrate that trade has diverse effects on the urban-rural income gap in various regions. One possible reason is that variances in the effects of trade on the urban-rural income gap are caused by differences in regional openness.

For the eastern regions, because of the implementation of an unbalanced foreign trade strategy, which is characterised by the priority of greater foreign exposure. The trade development level in the eastern regions is higher than that in the central and western regions. The eastern regions gradually eradicated trade development based on the growth of the trade scale, and started to transform the growth pattern of foreign trade. This means that the growth model of foreign trade in the western regions changed from a scale-oriented to a quality-oriented trade and, consequently, intensified competition in the domestic product and labour markets. The substitution of the production factors of import for labour is strengthened, and enterprises' preference for skilled labourers was changed. Consequently, the promotion of trade develop- ment on the employment of unskilled workers is weakened, and the urban-rural income gap is expanded. On the whole, in the eastern regions, the biased effect of employment quality is obvious (Wei \& Zhao, 2012). 


\section{Table 3}

Regression results (2) of trade openness and the urban-rural income gap at regional level, spanning from 1986 to 2000

\begin{tabular}{|c|c|c|c|c|c|c|c|c|c|}
\hline \multicolumn{10}{|c|}{ Explained variable: Theil Index } \\
\hline & \multicolumn{3}{|c|}{ Eastern regions } & \multicolumn{3}{|c|}{ Central regions } & \multicolumn{3}{|c|}{ Western regions } \\
\hline & (1) & (2) & (3) & (4) & (5) & (6) & (7) & (8) & (9) \\
\hline \multirow{2}{*}{ C } & $0.3841^{* * *}$ & $0.33222^{* *}$ & $0.3691^{\cdots *}$ & -0.1420 & -0.1285 & $-0.1867^{*}$ & 0.1367 & 0.1598 & $0.2291^{* *}$ \\
\hline & $(4.96)$ & $(4.50)$ & $(4.53)$ & $(-1.38)$ & $(-1.22)$ & $(-1.81)$ & $(1.24)$ & $(1.50)$ & $(2.03)$ \\
\hline \multirow{2}{*}{ Trade } & $0.0143^{\text {tat* }}$ & & & -0.1664 & & & $-0.14799^{* *}$ & & \\
\hline & $(3.65)$ & & & $(-2.77)$ & & & $(-2.26)$ & & \\
\hline \multirow{2}{*}{ Export } & & $0.0363^{* * *}$ & & & $-0.1573^{*}$ & & & $-0.2187^{* * *}$ & \\
\hline & & $(4.86)$ & & & $(-1.67)$ & & & $(-2.93)$ & \\
\hline \multirow{2}{*}{ Import } & & & $0.0123^{*}$ & & & $-0.3084^{* * * *}$ & & & 0.0702 \\
\hline & & & $(1.91)$ & & & $(-2.94)$ & & & $(0.53)$ \\
\hline \multirow{2}{*}{ Private } & $-0.0846^{\text {nat }}$ & $-0.0816^{* * *}$ & $-0.0725^{* * *}$ & $0.3316^{* * *}$ & $0.3377^{* * *}$ & $0.3346^{* * *}$ & $-0.1030^{* * *}$ & $-0.1050^{* * *}$ & $-0.0724^{*}$ \\
\hline & $(-4.08)$ & $(-4.17)$ & $(-3.41)$ & $(5.96)$ & $(6.00)$ & $(6.04)$ & $(-2.69)$ & $(-2.80)$ & $(-1.94)$ \\
\hline \multirow{2}{*}{ FDI } & 0.0463 & 0.0251 & $0.0820^{\circ}$ & $-0.9955^{\ldots *}$ & $-1.1029^{* * * *}$ & $-0.9155^{* * *}$ & $-0.5825^{* \prime}$ & $-0.6053^{* \cdots *}$ & -0.6496 \\
\hline & $(1.06)$ & $(0.58)$ & $(1.90)$ & $(-5.66)$ & $(-6.37)$ & $(-5.00)$ & $(-2.51)$ & $(-2.64)$ & $(-2.76)$ \\
\hline \multirow{2}{*}{ Employ } & $0.0608^{* *}$ & $0.0832^{* * *}$ & $0.0510^{* *}$ & $-0.1873^{\text {t*** }}$ & $-0.1946^{* * *}$ & $-0.1733^{* * *}$ & $0.2642^{* * * *}$ & $0.2548^{* * *}$ & $0.2188^{* *+1}$ \\
\hline & $(2.42)$ & $(3.29)$ & $(1.98)$ & $(-4.66)$ & $(-4.76)$ & $(-4.30)$ & $(6.52)$ & $(6.70)$ & $(5.34)$ \\
\hline \multirow{2}{*}{ Unemploy } & -0.0011 & -0.0022 & -0.0013 & $0.0095^{\text {t** }}$ & $0.0092^{\text {tow* }}$ & $0.0093^{* * *}$ & -0.0005 & -0.0004 & -0.0007 \\
\hline & $(-0.83)$ & $(-1.64)$ & $(-0.91)$ & $(3.15)$ & $(3.04)$ & $(3.11)$ & $(-0.48)$ & $(-0.37)$ & $(-0.74)$ \\
\hline \multirow{2}{*}{ Lnagdp } & $-0.0138^{*}$ & -0.0123 & -0.0128 & 0.0077 & 0.0053 & 0.0104 & 0.0101 & 0.00885 & -0.0003 \\
\hline & $(-1.69)$ & $(-1.54)$ & $(-1.52)$ & $(0.64)$ & $(0.44)$ & $(0.87)$ & $(0.83)$ & $(0.76)$ & $(-0.02)$ \\
\hline \multirow{2}{*}{ Capital } & $0.0007^{* *}$ & $0.0008^{* *}$ & $0.0007^{*}$ & 0.0010 & 0.0005 & 0.0012 & $-0.0012^{* *}$ & $-0.0013^{* *}$ & -0.0005 \\
\hline & (2.05) & $(2.48)$ & (1.93) & $(0.95)$ & $(0.49)$ & $(1.07)$ & $(-2.05)$ & $(-2.25)$ & $(-0.97)$ \\
\hline \multirow{2}{*}{ Education } & $-0.0203^{t * * *}$ & -0.0166 & $-0.0199^{* * *}$ & -0.0010 & -0.0004 & -0.0002 & $-0.0169^{* * *}$ & $-0.0178^{* * *}$ & $-0.0205^{4+\ldots}$ \\
\hline & $(-6.58)$ & $(-5.73)$ & $(-5.88)$ & $(-0.16)$ & $(-0.07)$ & $(-0.03)$ & $(-4.25)$ & $(-4.68)$ & $(-5.04)$ \\
\hline R2 & 0.77 & 0.78 & 0.76 & 0.73 & 0.72 & 0.73 & 0.72 & 0.73 & 0.72 \\
\hline Adj-R ${ }^{2}$ & 0.76 & 0.77 & 0.75 & 0.70 & 0.70 & 0.71 & 0.70 & 0.71 & 0.70 \\
\hline
\end{tabular}

For the central and western regions, the effect of trade scale is not fully functioning, and creating employment by means of foreign trade is still an important way to solve the problems of surplus rural labour and urban unemployment and to narrow the urban-rural income gap. According to China's Migrant Workers Survey Report released by the National Bureau of Statistics, the employment of migrant worker in the central regions increased by 4.2 per cent in 2011 , and in the western regions increased by 6.7 per cent, suggesting increases that are 1.1 per cent and 3.6 per cent higher than the increase in the eastern regions. ${ }^{1}$ This demonstrates that the marginal effect of employment created by trade in the central and western regions is greater than in the eastern regions. Consequently, it is practically significant for the central and western regions to expand trade scale, strengthen foreign exposure, and tap the potential of creating employment through trade. The increase of employment can significantly promote the income of rural labourers, improving the utilisation rate of labours, and narrow the urban-rural income gap. On the whole, the effect of employment expansion caused by an increase in trade scale is obvious (Wei \& Zhao, 2012).

Unlike the regression results at national level, trade factors affect the urban-rural income gap in three regions, but they are different from each other in significance, directions of influence and the degree of the influence. Further studies should be conducted on the effect of trade structure and trade patterns on the three regions.

Furthermore, from the perspective of other 
explanatory variables, the non-trade factors that have significant effects on both explained variables (Income and Theil) in the three regions are different. In the eastern regions, it is trade structure and the ratio of urban fixed-asset investment to rural fixed-asset investment that affect the urban-rural income gap. In the central regions, it is the degree of denationalisation, openness to foreign direct investment, employment structure, and urban unemployment rate that affect the urban-rural income gap. In the western regions, it is openness to foreign direct investment, employment structure, and average level of education that affect the urban-rural income gap. It is demonstrated that the non-trade factors that affect the urban-rural income gap in the three regions are different, and this situation is caused by differences between factor endowment and economic development.

\subsection{Analysis from the perspective of product structure of trade}

In order to study the effects of various products on the urban-rural income gap, this paper classifies products into labour-intensive (Labtrade) and high-tech products (Tectrade), according to technological content. This paper conducts research at both national and regional levels, focusing on the variation tendency since 2000. The regression results are shown in Tables 4 and 5.

a) At national level, regressions based on the ratio of urban to rural income and the Theil Index both demonstrate that the correlation coefficient of high-tech products is significantly positive while the effect of labour-intensive products is not significant. It is demonstrated that the development of high-tech product trade has significantly expanded the urban-rural income gap in China since 2000. This situation is caused by the biased effect of employment quality and an imbalance in the employment structure in the labour market caused by a trade structure upgrade. Since the start of the $21^{\text {st }}$ century, with the high-tech industry based on the information industry transferring to developing countries, product compositions in China have changed from labour-intensive to capital-intensive products and high- or middle-tech-intensive products.
The labour market is in favour of skilled workers and reduces the demand for unskilled workers. It is difficult to reverse this situation, as China has an abundance of unskilled workers and shortage of skilled workers. By the path of trade structure upgrade $\rightarrow$ biased effect of employment quality $\rightarrow$ expansion of wage gap, foreign trade expands the income gap between urban residents (based on skilled workers) and rural residents (based on unskilled workers).

b) The regression results at regional level demonstrate that the variances in effect of trade structure on the three regions are significant. In the eastern regions, both the trade of labour-intensive and high-tech products have significantly positive correlations with the dependent variables, and the effect of labour-intensive products on the expansion of the urban-rural income gap is more significant. In the central regions, the regression coefficients of the trade of labour-intensive and high-tech products are negative, but their significance is not stable. In the western regions, the regression coefficient of the trade of labour-intensive products is negative, and that of the trade of high-tech products is positive; however, neither of them is significant. In conclusion, the trade of products of any kind significantly expands the urban-rural income gap in the eastern regions, and the trade of products of any kind significantly narrows the urban-rural income gap in the central regions. In the western regions, the trade of labourintensive products narrows the urban-rural income gap, and the trade of techintensive products expands the urban-rural income gap. These effects in the eastern regions are great, most significant and stable, and the effects in the western and central regions are small and not significant.

The trading of products of different kinds has diverse effects on the urban-rural income gap, and this is closely related to trade structure and the structure of the labour market. On the whole, the reason why trade development expands the urban-rural income gap is because of the mismatch between the trade and labour 
market structures in the eastern regions. Similarly, because the trade and labour market structures are well matched in the central regions, the development of foreign trade has narrowed the urban-rural income gap. Trade and labour market structures are not well matched in the western regions and there is a lack of skilled workers, and therefore the trade of tech-intensive products expands the urban-rural income gap. Furthermore, from the perspective of other explanatory variables, the significances and correlation coefficients are nearly in accordance with the above as well as expectations.

Table 4

Regression results (1) of trade structure and the urban-rural income gap at both national and regional level: 2000 to 2010

\begin{tabular}{|c|c|c|c|c|c|c|c|c|}
\hline \multicolumn{9}{|c|}{ Explained variable: Ratio of urban income to rural income } \\
\hline & \multicolumn{4}{|c|}{ Trade of labour-intensive products } & \multicolumn{4}{|c|}{ Trade of high-tech products } \\
\hline & Nationwide & $\begin{array}{l}\text { Eastern } \\
\text { regions }\end{array}$ & $\begin{array}{l}\text { Central } \\
\text { regions }\end{array}$ & $\begin{array}{l}\text { Western } \\
\text { regions }\end{array}$ & Nationwide & $\begin{array}{l}\text { Eastern } \\
\text { regions }\end{array}$ & $\begin{array}{l}\text { Central } \\
\text { regions }\end{array}$ & $\begin{array}{l}\text { Western } \\
\text { regions }\end{array}$ \\
\hline \multirow{2}{*}{ C } & $7.7835^{* * *}$ & $4.0445^{* *}$ & 0.5612 & 3.7487 & $8.1045^{\text {*** }}$ & $3.9082^{* * * *}$ & -1.0575 & $5.8360^{* *}$ \\
\hline & $(5.92)$ & $(2.24)$ & $(0.25)$ & $(1.41)$ & $(6.47)$ & $(2.11)$ & $(-0.48)$ & $(2.23)$ \\
\hline \multirow{2}{*}{ Labtrade } & 0.0364 & $0.1532^{\text {*t*k }}$ & $-0.1483^{*}$ & $-0.1016^{* *}$ & & & & \\
\hline & $(1.32)$ & $(5.76)$ & $(-1.67)$ & $(-2.14)$ & & & & \\
\hline \multirow{2}{*}{ Tectrade } & & & & & $0.0381^{* *}$ & $0.0892^{* * *}$ & -0.0383 & 0.0021 \\
\hline & & & & & $(2.36)$ & $(5.23)$ & $(-1.09)$ & $(0.08)$ \\
\hline \multirow{2}{*}{ Private } & -0.6835 & $-1.4807^{* \star}$ & $3.9970^{\text {*** }}$ & $1.4620^{*}$ & -0.8355 & -0.7993 & $4.3275^{* * *}$ & 0.7793 \\
\hline & $(-1.28)$ & $(-2.61)$ & $(4.41)$ & (1.84) & $(-1.58)$ & $(-1.42)$ & $(4.54)$ & $(0.87)$ \\
\hline \multirow{2}{*}{ FDI } & $-6.4300^{* * *}$ & -1.3708 & $-13.2286^{* * *}$ & -7.0998 & $-7.3387^{\star * *}$ & $-3.4013^{* * *}$ & $-12.0032^{* * *}$ & -4.6200 \\
\hline & $(-5.48)$ & $(-1.48)$ & $(-6.60)$ & $(-1.39)$ & $(-5.99)$ & $(-3.31)$ & $(-6.17)$ & $(-0.85)$ \\
\hline \multirow{2}{*}{ Employ } & 0.0805 & $1.1113^{* *}$ & $-1.4990^{* * * *}$ & $2.8423^{* * * *}$ & 0.1653 & 1.0520 & $-1.8194^{* * *}$ & $2.1653^{\text {**** }}$ \\
\hline & $(0.23)$ & $(2.22)$ & $(-3.05)$ & $(3.75)$ & $(0.49)$ & (2.05) & $(-3.75)$ & $(3.07)$ \\
\hline \multirow{2}{*}{ Unemploy } & -0.0689 & $-0.0523^{* \star *}$ & 0.0699 & $-0.3363^{* * *}$ & $-0.0719^{* *}$ & $-0.0564^{* \star *}$ & 0.0734 & $-0.3319^{* * *}$ \\
\hline & $(-2.33)$ & $(-2.77)$ & $(1.63)$ & $(-4.04)$ & $(-2.48)$ & $(-2.93)$ & $(1.55)$ & $(-3.88)$ \\
\hline \multirow{2}{*}{ Lnagdp } & -0.2186 & -0.2016 & 0.1627 & 0.0166 & $-0.2259^{* * *}$ & -0.1189 & 0.0771 & -0.1977 \\
\hline & $(-1.64)$ & $(-1.05)$ & $(0.71)$ & $(0.06)$ & $(-2.02)$ & $(-0.62)$ & $(0.35)$ & $(-0.78)$ \\
\hline \multirow{2}{*}{ Capital } & $0.0197^{* \star *}$ & $0.0239^{* * *}$ & 0.0101 & -0.0024 & $0.0201^{* * *}$ & $0.0176^{* *}$ & 0.0095 & 0.0024 \\
\hline & $(3.76)$ & (3.43) & $(0.70)$ & $(-0.26)$ & $(4.14)$ & $(2.59)$ & $(0.64)$ & $(0.26)$ \\
\hline \multirow{2}{*}{ Education } & $-0.3014^{* * * *}$ & $-0.1281^{\text {t*** }}$ & 0.0201 & -0.03012 & $-0.3089^{\text {*t*k }}$ & $-0.1137^{* * *}$ & 0.0750 & $-0.1300^{*}$ \\
\hline & $(-6.86)$ & $(-3.05)$ & $(0.25)$ & $(-0.36)$ & $(-7.07)$ & $(-2.63)$ & (1.08) & $(-1.70)$ \\
\hline R2 & 0.76 & 0.71 & 0.69 & 0.67 & 0.77 & 0.70 & 0.69 & 0.65 \\
\hline Adj- $R^{2}$ & 0.73 & 0.66 & 0.63 & 0.60 & 0.74 & 0.65 & 0.62 & 0.58 \\
\hline
\end{tabular}

\subsection{Analysis from the perspective of trade mode}

Tables 6 and 7 provide the regression results based on general trade and processing trade. Specifically, at the national level, the regression coefficient of the processing trade is significantly positive, and the regression coefficient of general trade is positive, but without a stable significance. The regression coefficient of general trade in Table 6 is not significant, and Table 7 demonstrates a weak yet positive correlation. This means that processing and general trades expand the urban-rural income gaps at national level, and the effect of the processing trade is more significant than that of general trade. At a regional level, various trade mode have different effects on certain regions. General and processing trades in the eastern regions have positive and significant correlations with the urban-rural income gap, and general and processing trades in the central regions have negative yet insignificant correlations with the urban-rural income gap. In the western regions, 
general trade has positive yet insignificant correlations with the urban-rural income gap, and the effect of processing trade is uncertain. In other words, the development of general and processing trades in the eastern regions will significantly expand the urban-rural income gap, and in the central regions it will narrow the urban-rural income gap, but the effect is not significant. General trade in the western regions will expand the urban-rural income gap, while the effect is insignificant, and the effect of processing trade is uncertain. In particular, the effect of general and processing trades in the eastern regions on the urban-rural income gap is significant, which is in accordance with the regression results at national level; however, the effect of general trade on the urban-rural income gap in the eastern regions is greater than that of processing trade, which is in disagreement with the regression results at national level.

Table 5

Regression results (2) of trade structure and the urban-rural income gap at both national and regional level: 2000 to 2010

\begin{tabular}{|c|c|c|c|c|c|c|c|c|}
\hline \multicolumn{9}{|c|}{ Explained variable: Theil Index } \\
\hline & \multicolumn{4}{|c|}{ Trade of Labour-intensive products } & \multicolumn{4}{|c|}{ Trade of high-tech products } \\
\hline & Nationwide & $\begin{array}{l}\text { Eastern } \\
\text { regions }\end{array}$ & $\begin{array}{l}\text { Central } \\
\text { regions }\end{array}$ & $\begin{array}{l}\text { Western } \\
\text { regions }\end{array}$ & Nationwide & $\begin{array}{l}\text { Eastern } \\
\text { regions }\end{array}$ & $\begin{array}{l}\text { Central } \\
\text { regions }\end{array}$ & $\begin{array}{l}\text { Western } \\
\text { regions }\end{array}$ \\
\hline \multirow{2}{*}{ C } & $0.7438^{4 * *}$ & $0.5461^{* * *}$ & -0.0374 & $0.6108^{* *}$ & $0.7749^{* \cdots *}$ & $0.5072^{\text {t*t* }}$ & -0.1710 & $0.7872^{* * * *}$ \\
\hline & $(6.63)$ & $(3.64)$ & $(-0.15)$ & $(2.30)$ & $(7.27)$ & $(3.22)$ & $(-0.72)$ & $(3.12)$ \\
\hline \multirow{2}{*}{ Labtrade } & 0.0037 & $0.0116^{\cdots \cdots}$ & -0.0116 & -0.0042 & & & & \\
\hline & $(1.57)$ & $(5.27)$ & $(-1.22)$ & $(-0.89)$ & & & & \\
\hline \multirow{2}{*}{ Tectrade } & & & & & $0.0038^{\cdots *}$ & $0.0059^{* \cdots *}$ & -0.0036 & 0.0040 \\
\hline & & & & & $(2.78)$ & $(4.10)$ & $(-0.96)$ & $(1.64)$ \\
\hline \multirow{2}{*}{ Private } & $-0.1445^{* * * *}$ & $-0.2015^{* * *}$ & $0.3978^{\text {ta* }}$ & -0.0403 & $-0.1595^{* * *}$ & $-0.1487^{*+* *}$ & $0.4282^{* * *}$ & $-0.1440^{*}$ \\
\hline & $(-3.18)$ & $(-4.28)$ & $(4.09)$ & $(-0.51)$ & $(-3.54)$ & $(-3.11)$ & $(4.22)$ & $(-1.67)$ \\
\hline \multirow{2}{*}{ FDI } & $-0.4441^{* * *}$ & -0.0809 & $-1.1150^{* * *}$ & $-0.8491^{*}$ & -0.5354 & $-0.2151^{* *}$ & $-1.0153^{* * *}$ & -0.4686 \\
\hline & $(-4.44)$ & $(-1.06)$ & $(-5.19)$ & $(-1.67)$ & $(-5.13)$ & $(-2.47)$ & $(-4.90)$ & $(-0.90)$ \\
\hline \multirow{2}{*}{ Employ } & 0.0356 & $0.0871^{* *}$ & $-0.1524^{\text {*t** }}$ & $0.1813^{* *}$ & 0.0443 & $0.0870^{* *}$ & $-0.1790^{* * * *}$ & $0.1612^{* *}$ \\
\hline & $(1.17)$ & $(2.10)$ & $(-2.89)$ & $(2.40)$ & $(1.54)$ & $(1.99)$ & $(-3.47)$ & $(2.37)$ \\
\hline \multirow{2}{*}{ Unemploy } & $-0.0051^{* *}$ & -0.0026 & 0.0024 & $-0.0236^{* * *}$ & $-0.0054^{* *}$ & $-0.0031^{*}$ & 0.0031 & $-0.0245^{\ldots *}$ \\
\hline & $(-2.01)$ & $(-1.65)$ & $(0.52)$ & $(-2.84)$ & $(-2.18)$ & $(-1.91)$ & $(0.61)$ & $(-2.97)$ \\
\hline \multirow{2}{*}{ Lnagdp } & $-0.0269^{* *}$ & $-0.0282^{*}$ & 0.0013 & -0.0199 & -0.0274 & -0.0176 & -0.0042 & -0.0334 \\
\hline & $(-2.3597)$ & $(-1.77)$ & $(0.05)$ & $(-0.76)$ & $(-2.89)$ & $(-1.08)$ & $(-0.18)$ & $(-1.37)$ \\
\hline \multirow{2}{*}{ Capital } & $0.0011^{* *}$ & $0.0015^{* *}$ & 0.0005 & 0.0001 & $0.0011^{\prime * *}$ & 0.0009 & 0.0005 & 0.0003 \\
\hline & $(2.3629)$ & $(2.57)$ & $(0.34)$ & $(0.14)$ & $(2.64)$ & $(1.59)$ & $(0.33)$ & $(0.34)$ \\
\hline \multirow{2}{*}{ Education } & $-0.0344^{* t * *}$ & $-0.0262^{* * *}$ & 0.0077 & $-0.0185^{* *}$ & $-0.0352^{* * *}$ & $-0.0254^{*+* *}$ & 0.0118 & $-0.0268^{* * *}$ \\
\hline & $(-9.1928)$ & $(-7.53)$ & $(0.91)$ & $(-2.23)$ & $(-9.46)$ & $(-6.93)$ & $(1.59)$ & $(-3.64)$ \\
\hline R2 & 0.82 & 0.86 & 0.67 & 0.65 & 0.82 & 0.85 & 0.66 & 0.66 \\
\hline Adj- $R^{2}$ & 0.80 & 0.84 & 0.60 & 0.59 & 0.800 & 0.82 & 0.59 & 0.60 \\
\hline
\end{tabular}

The proportion of processing trade to total trade is approximately 50 per cent. According to the data from customs, the proportion of processing trade to total trade is approximately 55 per cent, spanning 1997 to 2005, and even during economic encounters with the sub-prime mortgage crisis and the European debt crisis in 2008, the export of processing trade was 835.42 billion dollars, consisting of
44 per cent of total exports. At the same time, processing trade is grouped in the eastern regions. In 2011, the export and import of processing trade in the central and western regions were 84.54 billion dollars, consisting of 6.5 per cent of the total processing trade ${ }^{2}$. Consequently, the effect of processing trade on the eastern regions is great and significant. At the same time, processing and general trades 
have great and significant effects on the local urban-rural income gap. Processing and general trades have an effect on the narrowing of the income gap, but the effect is slight and not significant. This demonstrates that the eastern regions achieve results in transforming their trade development pattern both in the fields of processing trade and general trade.

Table 6

Regression results (1) of trade mode and the urban-rural income gap at both national and regional level: 2000 to 2010

\begin{tabular}{|c|c|c|c|c|c|c|c|c|}
\hline \multicolumn{9}{|c|}{ Explained variable: Ratio of urban income to rural income } \\
\hline & \multicolumn{4}{|c|}{ General trade } & \multicolumn{4}{|c|}{ Processing trade } \\
\hline & Nationwide & $\begin{array}{l}\text { Eastern } \\
\text { regions }\end{array}$ & $\begin{array}{l}\text { Central } \\
\text { regions }\end{array}$ & $\begin{array}{l}\text { Western } \\
\text { regions }\end{array}$ & Nationwide & $\begin{array}{l}\text { Eastern } \\
\text { regions }\end{array}$ & $\begin{array}{l}\text { Central } \\
\text { regions }\end{array}$ & $\begin{array}{c}\text { Western } \\
\text { regions }\end{array}$ \\
\hline \multirow{2}{*}{ C } & $8.0922^{\text {**** }}$ & $5.2836^{\star * \star}$ & -0.1203 & $7.6531^{* * *}$ & $9.2680^{\text {**** }}$ & $7.0351^{* \star *}$ & -0.8077 & $7.3774^{* *}$ \\
\hline & $(6.13)$ & $(2.79)$ & $(-0.05)$ & $(2.93)$ & $(7.04)$ & $(3.81)$ & $(-0.33)$ & $(3.08)$ \\
\hline \multirow{2}{*}{ Gentrade } & 0.0419 & $0.1051^{* * *}$ & -0.0764 & 0.0114 & & & & \\
\hline & $(1.31)$ & $(3.12)$ & $(-0.89)$ & $(0.19)$ & & & & \\
\hline \multirow{2}{*}{ Protrade } & & & & & $0.0538^{* * *}$ & $0.0730^{* * *}$ & -0.0212 & -0.0148 \\
\hline & & & & & $(3.28)$ & $(4.92)$ & $(-0.59)$ & $(-0.57)$ \\
\hline \multirow{2}{*}{ Private } & $-0.9945^{*}$ & $-1.2823^{* *}$ & $3.8802^{* * *}$ & 0.2333 & $-1.3279^{* *}$ & $-1.1966^{* *}$ & $3.8917^{* * *}$ & 0.5228 \\
\hline & $(-1.71)$ & $(-2.08)$ & $(4.10)$ & $(0.24)$ & $(-2.41)$ & $(-2.11)$ & (3.99) & $(0.67)$ \\
\hline \multirow{2}{*}{ FDI } & $-4.8770^{* * *}$ & -0.2291 & $-12.0366^{* * *}$ & -4.9019 & $-5.8261^{\star \star * *}$ & $-1.9079^{* *}$ & $-11.2947^{* * *}$ & -5.5505 \\
\hline & $(-4.13)$ & $(-0.25)$ & $(-4.97)$ & $(-0.93)$ & $(-4.88)$ & $(-2.16)$ & $(-5.06)$ & $(-1.12)$ \\
\hline \multirow{2}{*}{ Employ } & 0.2071 & 0.6161 & $-1.5646^{* * *}$ & $2.0847^{* * *}$ & 0.1876 & 0.3956 & $-1.5373^{* * * *}$ & 2.1574 \\
\hline & $(0.59)$ & $(1.12)$ & $(-3.25)$ & $(2.98)$ & $(0.55)$ & $(0.76)$ & $(-3.19)$ & (3.20) \\
\hline \multirow{2}{*}{ Unemploy } & $-0.0753^{* *}$ & $-0.0644^{* * *}$ & 0.0529 & $-0.2650^{* * *}$ & $-0.0792^{* * *}$ & $-0.0922^{* \star *}$ & 0.0393 & $-0.2660^{* *}$ \\
\hline & $(-2.50)$ & $(-2.77)$ & $(1.22)$ & $(-3.40)$ & $(-2.74)$ & $(-4.68)$ & $(0.95)$ & $(-3.41)$ \\
\hline \multirow{2}{*}{ Lnagdp } & $-0.2536^{* *}$ & -0.2487 & 0.1525 & -0.4240 & $-0.3338^{* \star * *}$ & $-0.3256^{*}$ & 0.1159 & $-0.4114^{\star}$ \\
\hline & $(-2.00)$ & $(-1.24)$ & $(0.58)$ & $(-1.65)$ & $(-2.96)$ & $(-1.78)$ & $(0.44)$ & $(-1.74)$ \\
\hline \multirow{2}{*}{ Capital } & $0.0198^{* * *}$ & $0.0148^{*}$ & 0.0064 & 0.0087 & $0.0219^{* * *}$ & $0.0198^{* * *}$ & 0.0072 & 0.0086 \\
\hline & $(3.81)$ & $(1.90)$ & $(0.44)$ & $(0.97)$ & $(4.47)$ & $(2.66)$ & $(0.50)$ & $(0.98)$ \\
\hline \multirow{2}{*}{ Education } & $-0.2916^{\star \star * *}$ & $-0.1172^{* *}$ & -0.0007 & -0.0956 & $-0.2902^{\star * \star *}$ & $-0.1134^{* *}$ & 0.0086 & -0.0657 \\
\hline & $(-6.19)$ & $(-2.42)$ & $(-0.01)$ & $(-1.13)$ & $(-6.42)$ & $(-2.50)$ & $(0.10)$ & $(-0.83)$ \\
\hline R2 & 0.75 & 0.67 & 0.72 & 0.64 & 0.76 & 0.71 & 0.72 & 0.64 \\
\hline$A d j-R^{2}$ & 0.72 & 0.61 & 0.66 & 0.57 & 0.73 & 0.65 & 0.66 & 0.57 \\
\hline
\end{tabular}

Furthermore, the reduction effect of general and processing trades on the local income gap is mainly generated by means of employment expansion, which is caused by the increasing of foreign trade scale. The expansion effect of general and processing trades on the local income gap is mainly generated by the biased effect of employment quality, which is caused by the upgrading of the industrial structure.

\subsection{Endogenous problem and robustness test}

In previous studies on foreign trade and the urban-rural income gap, the endogenous problem is seldom mentioned. Reverse causality between foreign trade and the urban-rural income gap as well as measurement errors are likely to cause an endogenous problem, and this will lead to biased and inconsistent estimations. Consequently, considering the endogenous problems of the explained and the explanatory variables as well as the time-lag effect of the explanatory variables on the urban-rural income gap, we use two new models to test the regression results above. The first lagged explanatory variables are used in the first new model, and the first lagged explained variable is used in the second new model. This approach reduces the endogenous problem and tests the robustness of the regression results above. 


\section{Table 7}

Regression results (2) of trade mode and the urban-rural income gap at both national and regional level: 2000 to 2010

\begin{tabular}{|c|c|c|c|c|c|c|c|c|}
\hline \multicolumn{9}{|c|}{ Explained variable: Theil Index } \\
\hline & \multicolumn{4}{|c|}{ General trade } & \multicolumn{4}{|c|}{ Processing trade } \\
\hline & Nationwide & $\begin{array}{l}\text { Eastern } \\
\text { regions }\end{array}$ & Nationwide & $\begin{array}{l}\text { Eastern } \\
\text { regions }\end{array}$ & Nationwide & $\begin{array}{l}\text { Eastern } \\
\text { regions }\end{array}$ & Nationwide & $\begin{array}{l}\text { Eastern } \\
\text { regions }\end{array}$ \\
\hline \multirow{2}{*}{ C } & $0.7775^{* * *}$ & $0.6528^{* * *}$ & 0.0305 & $0.9514^{* * *}$ & $0.8761^{* * *}$ & $0.8308^{\star * \star *}$ & -0.0663 & $0.8179^{* * *}$ \\
\hline & $(7.05)$ & $(3.98)$ & $(0.12)$ & $(3.88)$ & $(7.98)$ & $(5.34)$ & $(-0.25)$ & $(3.60)$ \\
\hline \multirow{2}{*}{ Gentrade } & $0.0047^{*}$ & $0.0070^{* *}$ & -0.0116 & 0.0078 & & & & \\
\hline & $(1.76)$ & $(2.40)$ & $(-1.26)$ & $(1.41)$ & & & & \\
\hline \multirow{2}{*}{ Protrade } & & & & & $0.0051^{* * *}$ & $0.0064^{* \star *}$ & -0.0026 & 0.0012 \\
\hline & & & & & $(3.72)$ & (5.15) & $(-0.68)$ & $(0.47)$ \\
\hline \multirow{2}{*}{ Private } & $-0.1670^{* * *}$ & $-0.1807^{+* * *}$ & $0.3789^{* * * *}$ & $-0.1662^{*}$ & $-0.1924^{* * *}$ & $-0.1836^{* \star *}$ & $0.3759^{* * * *}$ & -0.0940 \\
\hline & $(-3.44)$ & $(-3.39)$ & $(3.74)$ & $(-1.83)$ & $(-4.19)$ & $(-3.84)$ & $(3.58)$ & $(-1.27)$ \\
\hline \multirow{2}{*}{ FDI } & $-0.2959^{* * *}$ & -0.0023 & $-1.0506^{* * *}$ & -0.6998 & $-0.3864^{* * *}$ & $-0.1397^{*}$ & $-0.9341^{\star \star *}$ & $-0.9111^{*}$ \\
\hline & $(-3.00)$ & $(-0.03)$ & $(-4.04)$ & $(-1.42)$ & $(-3.89)$ & $(-1.88)$ & $(-3.89)$ & $(-1.93)$ \\
\hline \multirow{2}{*}{ Employ } & 0.0371 & 0.0366 & $-0.1480^{\star \star *}$ & 0.0979 & 0.0364 & 0.0163 & $-0.1432^{\star \star \star *}$ & $0.1204^{*}$ \\
\hline & $(1.26)$ & $(0.77)$ & $(-2.87)$ & $(1.49)$ & $(1.27)$ & $(0.37)$ & $(-2.76)$ & $(1.88)$ \\
\hline \multirow{2}{*}{ Unemploy } & $-0.0056^{* *}$ & $-0.0038^{*}$ & 0.0004 & $-0.0208^{* * *}$ & $-0.0061^{* *}$ & $-0.0056^{* * * *}$ & -0.0016 & $-0.0210^{* * * *}$ \\
\hline & $(-2.23)$ & $(-1.90)$ & $(0.10)$ & $(-2.85)$ & $(-2.54)$ & $(-3.37)$ & $(-0.35)$ & $(-2.84)$ \\
\hline \multirow{2}{*}{ Lnagdp } & $-0.0312^{* * *}$ & $-0.0314^{*}$ & 0.0017 & $-0.0552^{* *}$ & $-0.0369^{* * *}$ & $-0.0444^{* \star *}$ & -0.0053 & $-0.0414^{*}$ \\
\hline & $(-2.94)$ & $(-1.82)$ & $(0.06)$ & $(-2.28)$ & $(-3.91)$ & $(-2.88)$ & $(-0.19)$ & $(-1.84)$ \\
\hline \multirow{2}{*}{ Capital } & $0.0011^{* * *}$ & 0.0008 & 0.0007 & 0.0011 & $0.0013^{* * *}$ & $0.0014^{* *}$ & 0.0008 & 0.0008 \\
\hline & (2.61) & $(1.18)$ & $(0.48)$ & $(1.30)$ & $(3.13)$ & $(2.16)$ & $(0.54)$ & $(0.94)$ \\
\hline \multirow{2}{*}{ Education } & $-0.0342^{* * *}$ & $-0.0254^{* * *}$ & 0.0005 & $-0.0271^{* * *}$ & $-0.0339^{* * *}$ & $-0.0244^{* * *}$ & 0.0024 & $-0.0225^{* * * *}$ \\
\hline & $(-8.69)$ & $(-6.05)$ & $(0.06)$ & $(-3.43)$ & $(-8.98)$ & $(-6.40)$ & $(0.27)$ & $(-3.01)$ \\
\hline R2 & 0.81 & 0.81 & 0.70 & 0.68 & 0.82 & 0.84 & 0.70 & 0.67 \\
\hline $\operatorname{Adj}-R^{2}$ & 0.79 & 0.78 & 0.64 & 0.62 & 0.80 & 0.82 & 0.64 & 0.62 \\
\hline
\end{tabular}

The regression results of the first new model in Table 8 demonstrate that correlations between trade factors and the urban-rural income gap are significantly positive, while correlations between trade factors, namely the trade of labour-intensive products and general trade, and the urban-rural income gap are not significant. The explanatory variables, from the perspective of trade openness, are significant, and the direction of influence of the urban unemployment rate, economic development, the ratio of urban fixed-asset investment to rural fixed-asset investment, and the average level of education, are in accordance with the regression results above. From the perspective of trade structure, the significance of openness to foreign direct investment, the ratio of urban fixed-asset investment to rural fixed-asset investment, and the average level of education is consistent. From the perspective of trade mode, the effects of openness to foreign direct investment and the average level of education on general and processing trades are significant, which is in accordance with the regression results above. 


\section{Table 8}

Regression results of first lagged explanatory variables

\begin{tabular}{|c|c|c|c|c|c|c|c|}
\hline & \multicolumn{7}{|c|}{ Explained variable: Ratio of urban income to rural income } \\
\hline & $\begin{array}{c}\text { Trade } \\
\text { openness }\end{array}$ & $\begin{array}{l}\text { Openness } \\
\text { to export }\end{array}$ & $\begin{array}{l}\text { Openness } \\
\text { to import }\end{array}$ & $\begin{array}{c}\text { Trade of } \\
\text { labour-intensive } \\
\text { products }\end{array}$ & $\begin{array}{l}\text { Trade of high- } \\
\text { tech products }\end{array}$ & $\begin{array}{c}\text { General } \\
\text { trade }\end{array}$ & $\begin{array}{c}\text { Processing } \\
\text { trade }\end{array}$ \\
\hline \multirow{2}{*}{ C } & $9.2773^{* * *}$ & $8.6470^{* * *}$ & $9.0330^{* * * *}$ & $7.7078^{\text {*** }}$ & $9.5693^{* * *}$ & $7.2934^{\text {**** }}$ & $7.9805^{* * *}$ \\
\hline & $(10.67)$ & $(9.90)$ & $(10.40)$ & $(5.61)$ & $(6.48)$ & $(5.43)$ & $(5.15)$ \\
\hline \multirow{2}{*}{ TRADE_1 } & $0.5785^{* * *}$ & $0.9808^{* * *}$ & $0.8255^{\text {*atk }}$ & 0.0335 & $0.1435^{* \star *}$ & 0.0186 & $0.0908^{* * *}$ \\
\hline & $(7.84)$ & $(6.16)$ & $(7.35)$ & $(1.17)$ & $(7.54)$ & $(0.58)$ & $(4.75)$ \\
\hline \multirow{2}{*}{ Private_1 } & $0.6442^{* *}$ & $0.8105^{* * *}$ & $0.6895^{* *}$ & -0.8742 & $1.2813^{* *}$ & -0.8447 & $1.5117^{* *}$ \\
\hline & $(2.29)$ & $(2.85)$ & $(2.44)$ & $(-1.56)$ & $(2.06)$ & $(-1.42)$ & $(2.25)$ \\
\hline \multirow{2}{*}{ FDI_1 } & -0.2371 & -0.0003 & 0.3223 & $-6.3130^{\text {*** }}$ & $-5.4552^{\text {t*k* }}$ & $-6.3187^{\text {*a* }}$ & $-3.6074^{* *}$ \\
\hline & $(-0.34)$ & $(0.001)$ & $(0.47)$ & $(-5.18)$ & $(-3.83)$ & $(-5.17)$ & $(-2.45)$ \\
\hline \multirow{2}{*}{ Employ_1 } & $-0.5409^{*}$ & -0.4933 & $-0.6652^{* *}$ & 0.1314 & $-1.3283^{* * *}$ & 0.2265 & $-1.2821^{* * *}$ \\
\hline & $(-1.79)$ & -1.59 & $(-2.19)$ & $(0.35)$ & $(-3.33)$ & $(0.63)$ & $(-3.03)$ \\
\hline \multirow{2}{*}{ Unemploy_1 } & -0.0115 & -0.0170 & -0.0079 & $-0.0699^{* *}$ & 0.0130 & $-0.0716^{* *}$ & 0.0155 \\
\hline & $(-1.01)$ & $(-1.47)$ & $(-0.69)$ & $(-2.27)$ & $(0.38)$ & $(-2.30)$ & $(0.43)$ \\
\hline \multirow{2}{*}{ Lnagdp_1 } & $-0.5903^{* * *}$ & $-0.5768^{* * *}$ & $-0.5275^{* * *}$ & -0.1881 & $-0.6880^{* * *}$ & -0.1256 & $-0.5049^{* * *}$ \\
\hline & $(-6.64)$ & $(-6.31)$ & $(-6.01)$ & $(-1.36)$ & $(-5.24)$ & $(-0.97)$ & $(-3.69)$ \\
\hline \multirow{2}{*}{ Capital_1 } & 0.0039 & 0.0077 & 0.0004 & $0.0173^{\text {*** }}$ & $0.0134^{* * *}$ & $0.0157^{n+*}$ & 0.0096 \\
\hline & $(0.85)$ & (1.64) & $(0.08)$ & $(3.20)$ & $(2.37)$ & $(2.97)$ & (1.59) \\
\hline \multirow{2}{*}{ Education_1 } & $-0.2663^{* * *}$ & $-0.2164^{* * *}$ & $-0.2981^{* \star *}$ & $-0.3022^{* * *}$ & $-0.3054^{\star \star * *}$ & $-0.3010^{* * *}$ & $-0.2734^{* * *}$ \\
\hline & $(-7.80)$ & $(-6.22)$ & $(-8.51)$ & $(-6.530$ & $(-5.91)$ & $(-6.39)$ & $(-0.52)$ \\
\hline R2 & 0.62 & 0.61 & 0.62 & 0.77 & 0.71 & 0.77 & 0.68 \\
\hline$A-R^{2}$ & 0.60 & 0.59 & 0.60 & 0.74 & 0.67 & 0.74 & 0.63 \\
\hline
\end{tabular}

The regression results of the second new model in Table 9 demonstrate that the coefficient of the explanatory variables and their significances are without notable changes, irrespective of perspective (trade openness, or trade structure, or trade mode). Furthermore, the regression results are optimised. The goodness of fit is improved, and the regression results of the variables are more in accordance with the regression results above. The goodness of fit of the degree of denationalisation, openness to foreign direct investment and employment structure is improved significantly.

On the whole, the coefficients and significance of variables in the two new models are in accordance with the regression results above, demonstrating the robustness of the estimation results in this paper.

Table 9

Regression results of first lagged ratio of urban income to rural income

\begin{tabular}{|c|c|c|c|c|c|c|c|}
\hline & \multicolumn{7}{|c|}{ Explained variables: Ratio of urban income to rural income } \\
\hline & $\begin{array}{l}\text { Trade } \\
\text { openness }\end{array}$ & $\begin{array}{l}\text { Openness } \\
\text { to export }\end{array}$ & $\begin{array}{l}\text { Openness } \\
\text { to import }\end{array}$ & $\begin{array}{l}\text { Trade of labour- } \\
\text { intensive products }\end{array}$ & $\begin{array}{l}\text { Trade of high- } \\
\text { tech products }\end{array}$ & General trade & $\begin{array}{l}\text { Processing } \\
\text { trade }\end{array}$ \\
\hline \multirow{2}{*}{ C } & $4.4906^{* * * *}$ & $4.1462^{* * *}$ & $4.0742^{* * *}$ & $4.4560^{* * *}$ & $4.0870^{* * *}$ & $3.6952^{* * *}$ & $4.7265^{* * *}$ \\
\hline & $(7.25)$ & $(7.00)$ & $(6.51)$ & $(3.73)$ & $(3.49)$ & (3.09) & $(4.16)$ \\
\hline \multirow{2}{*}{ Income_1 } & $0.3657^{* * *}$ & $0.3928^{* * *}$ & $0.3769^{* * *}$ & $0.3821^{* * *}$ & $0.3689^{* * *}$ & $0.3714^{* * *}$ & $0.3742^{* * *}$ \\
\hline & $(14.49)$ & $(16.71)$ & $(14.39)$ & $(10.04)$ & $(9.73)$ & $(9.71)$ & $(10.09)$ \\
\hline \multirow{2}{*}{ TRADE } & $0.3120^{* * * *}$ & $0.6617^{* * *}$ & $0.3466^{* * *}$ & $0.0689^{* * *}$ & $0.0347^{* *}$ & 0.0381 & $0.0572^{* * *}$ \\
\hline & $(5.85)$ & $(6.26)$ & $(4.15)$ & (2.83) & $(2.42)$ & (1.38) & $(4.20)$ \\
\hline \multirow{2}{*}{ Private } & -0.1632 & -0.0598 & -0.0770 & 0.4567 & 0.4547 & 0.4687 & 0.1676 \\
\hline & $(-0.84)$ & $(-0.32)$ & $(-0.39)$ & $(0.93)$ & $(0.91)$ & $(0.87)$ & $(0.34)$ \\
\hline
\end{tabular}




\begin{tabular}{|c|c|c|c|c|c|c|c|}
\hline \multirow{2}{*}{ FDI } & $-3.1680^{* * * *}$ & $-3.2943^{* * *}$ & $-2.7580^{* * * *}$ & $-7.0649^{* * * *}$ & $-7.8689^{* * * *}$ & $-7.0101^{* * *}$ & -8.0406 \\
\hline & $(-6.88)$ & $(-7.12)$ & $(-6.06)$ & $(-7.00)$ & $(-7.36)$ & $(-6.86)$ & $(-7.89)$ \\
\hline \multirow{2}{*}{ Employ } & $0.9512^{\text {tatk }}$ & $0.9840^{\circ * * *}$ & $0.8728^{\text {tatk }}$ & 0.0332 & 0.2533 & 0.2431 & 0.1802 \\
\hline & $(4.83)$ & $(5.00)$ & $(4.39)$ & $(0.11)$ & $(0.85)$ & $(0.80)$ & $(0.62)$ \\
\hline \multirow{2}{*}{ Unemploy } & -0.0003 & -0.0031 & 0.0011 & -0.0025 & -0.0161 & -0.0095 & -0.0072 \\
\hline & $(-0.04)$ & $(-0.42)$ & $(0.15)$ & $(-0.09)$ & $(-0.60)$ & $(-0.34)$ & $(-0.28)$ \\
\hline \multirow{2}{*}{ Lnagdp } & $-0.2509^{* * *}$ & $-0.2618^{* * *}$ & $-0.1988^{* * * *}$ & $-0.2529^{* *}$ & -0.1408 & -0.1220 & $-0.2223^{* \prime}$ \\
\hline & $(-4.22)$ & $(-4.40)$ & $(-3.38)$ & $(-2.15)$ & $(-1.43)$ & $(-1.10)$ & $(-2.3)$ \\
\hline \multirow{2}{*}{ Capital } & $0.0068^{* * *}$ & $0.0090^{* * * *}$ & 0.0050 & $0.0136^{* * *}$ & $0.0112^{* * * *}$ & $0.0104^{* * *}$ & 0.0136 \\
\hline & $(2.17)$ & $(2.84)$ & $(1.57)$ & (3.03) & (2.63) & (2.34) & (3.26) \\
\hline \multirow{2}{*}{ Education } & $-0.1396^{* * *}$ & $-0.1042^{* * * *}$ & $-0.1480^{* \text { *** }}$ & $-0.1961^{* * *}$ & $-0.2016^{* * *}$ & $-0.1975^{* * *}$ & $-0.1977^{*}$ \\
\hline & $(-6.08)$ & $(-4.62)$ & $(-6.12)$ & $(-4.92)$ & $(-4.99)$ & $(-4.79)$ & $(-5.06)$ \\
\hline R2 & 0.84 & 0.84 & 0.84 & 0.84 & 0.84 & 0.84 & 0.85 \\
\hline$A-R^{2}$ & 0.83 & 0.83 & 0.83 & 0.82 & 0.82 & 0.81 & 0.83 \\
\hline
\end{tabular}

5

\section{Conclusions and recommendations}

\subsection{Conclusions}

From the perspective of trade scale, trade structure and trade mode, this paper made use of panel data from 29 provinces spanning 1986 to 2010 to study the effect of foreign trade on the urban-rural income gap at national and regional levels.

a) From the perspective of trade openness, both export and import significantly expand the urban-rural income gap at national level, and the effect of export on the urban-rural income gap is greater than that of import. At regional level, foreign trade has various effects on the urban-rural income gap in certain regions, and there are differences in significance, the direction of influence and the degree of influence. In the eastern regions, both export and import significantly expand the urbanrural income gap, and the effect of export on the urban-rural income gap is greater than that of import, which is in accordance with the regression results at national level. In the central regions, foreign trade significantly narrows the urban-rural income gap and import has a greater effect on the narrowing of the urban-rural income gap than export does. In the western regions, export significantly narrows the urbanrural income gap, but the effect of import is not significant.

b) From the perspective of trade structure, the effect of the trade of high-tech products on the urban-rural income gap at national level is expansive and significant, and the effect of trade of labour-intensive products is also expansive but not significant. At the regional level, the effects of products of different kinds on the urban-rural income gap in the various regions are dissimilar. In the eastern regions, the trade of products of both kinds contributes significantly to the expansion of the urban-rural income gap, and the trade of labour-intensive product has a greater effect on the expansion of the urban-rural income gap. In the central regions, the trade of products of both kinds contributes to the narrowing of the urban-rural gap. In the western regions, the trade of labour-intensive products narrows the urban-rural income gap, and the trade of high-tech products expands the urban-rural income gap.

c) From the perspective of trade mode, at national level general and processing trades have an effect on the expansion of the urban-rural income gap, and the effect of processing trade is greater and more significant than that of general trade. At the regional level, the effects of various trade mode on different regions are not the same. In the eastern regions, the development of general and processing trades contributes to significantly expanding the urban-rural income gap. In the central regions, the development of general and processing trades contributes to significantly 
narrowing the urban-rural income gap. In the western regions, the development of general trade contributes to expanding the urban-rural income gap, but the effect of processing trade on the urban-rural income gap is uncertain.

\subsection{Recommendations}

Based on the research on the effect of trade scale on the urban-rural income gap, this paper conducted studies on the differences in the effects of various products and trade mode on the urban-rural income gap, and the results have practical significance. The results of this paper demonstrate that the development of trade in certain regions is different, and therefore has various effects on the urban-rural income gap. In the same regions, different products and trade mode have different effects on the urban-rural income gap. The effects of similar product and trade mode vary according to region. Consequently, government should formulate corresponding policies according to the development of trade in certain regions, and these policies can then achieve the expected effects in practice. Policies without consideration of regional differences are not adapted to national conditions. This is very important for both China and other developing countries, especially African countries.

The effect of foreign trade on the urbanrural income gap may be an expansion or a reduction effect. The effect is determined by means of the development of foreign trade and the structure of the labour market, and consequently, if the development tendency is well matched with the structure of the labour market, foreign trade will contribute to the narrowing of the urban-rural income gap, and vice versa. When the government makes an effort to promote economic growth by developing foreign trade in order to allow foreign trade to narrow the urban-rural income gap, government should select appropriate trade mode and product types according to the structure of the labour market, or it should adjust the structure of the labour market in order to develop foreign trade. In other words, for developing countries, the structure of the local labour market should be taken into consideration when a regional government is developing a strategy for the development of foreign trade. Other developing countries, especially South Africa, should also pay more attention to this aspect during the development of trade.

In the end, besides trade factors such as trade openness, the structure of trade and trade mode, this paper also demonstrated that government should consider non-trade factors that affect the urban-rural income gap, such as the human capital disparity caused by different educational statuses, urban-biased investment in fixed assets, and differences in government's regulation of markets. Taking non-trade factors into account, government should ease the expansion of the urban-rural income gap and allow more workers of different types to benefit from the development of foreign trade.

Endnotes:

1 Data source: State Statistics Bureau, http://www.stats.gov.cn/tjfx/fxbg/t20120427_402801903.htm.

2 Data source: website of customs statistics, http://www.hgtj.cn/.

\section{Acknowledgements}

This paper is supported by "The Social Science Research Fund of Education Ministry" (No. 10YJC790272), "National Social Science Research Fund" (No.10zd\&017, No.11AJL005) and "The Fundamental Research Funds for the Central University" (NO. 105563GK). We would like to express our great appreciation to the anonymous reviewers for their valuable comments on this manuscript as it developed.

\section{References}

AMITI, M. \& CAMERON, L. 2012. Trade liberalization and the wage skill premium: Evidence from Indonesia. Journal of International Economics, 87(2):277-287.

AMITI, M. \& DAVIS, D. 2008. Trade, firms, and wages: Theory and evidence. NBER Working paper, No. 141062008. 
BERNARD, A.B. \& JENSEN, J.B. 1997. Exporters, skill upgrading, and the wage gap. Journal of International Economics, 42:3-31.

BEYER, H. ROJAS P. \& VERGARA R. 1999. Trade liberalization and wage inequality. Journal of Development Economics, 59(1):103-123.

BHAGWATI, J. \& SRINIVASAN, T. 2002. Trade and poverty in the poor countries. American Economic Review, 92(2):180-183.

BHAGWATI, J. 2004. In defence of globalization. Oxford; Oxford University Press.

BRAMBILLA, I., LEDERMAN, D. \& PORTO, G. 2010. Exports, export destinations, and skills. NBER Working paper, No. 15995.

BUSTOS, P. 2007. The impact of trade on technology and skill upgrading evidence from Argentina. Working paper, No.1189.

CAI, F., \& WANG, M. 2009. Why didn't labor mobility narrow urban-rural income gap? Forward Position in Economics, (08).

CHEN, B., ZHANG, P. \& YANG, R. 2010. Government education investment, human capital investment and urban-rural income gap. Management World, (01).

DEARDORFF, A.V. 1982. The general validity of the Heckscher-Ohlin theorem. American Economic Review, 72(4):683-694.

EBENSTEIN, A. HARRISON, A. MARGARET, M. \& SHANNON P. 2009. Estimating the impact of trade and offshoring on American workers using the current population surveys. NBER Working paper, No. 15107. GOLDBERG, P.K. \& PAVCNIK, N. 2007. The effects of the Columbian trade liberalization on urban poverty. Globalization and Poverty, NBER Chapters, pp. 241-290.

HAN, J., LIU, R.J. \& ZHANG, J.S. 2012. Globalization and wage inequality: Evidence from urban China. Journal of International Economics, 87(2):288-297.

HARRISON, A. \& HANSON, G.H. 1999. Trade liberalization and wage inequality in Mexico. Industrial and Labor Relations Review, 52(2):271-288.

HARRISON, A., MCLAREN, J. \& MARGARET, S.M. 2010. Recent findings on trade and inequality. NBER Working Paper, No. 16425.

HASAN, R. \& JANDOC, K.R. 2010. Trade liberalization and wage inequality in the Philippines. University of the Philippines, School of Economics. Discussion paper, No. 2010-06.

HASKEL, J. \& SLAUGHTER, M.J. 2001. Trade, technology and UK wage inequality. The Economic Journal, 3,111(468):163-187.

HUMMELS, D., JORGENSEN, R., MUNCH, J. \& XIANG, C. 2010. The wage and employment effects of outsourcing: Evidence from Danish matched worker-firm data. Working paper.

KANBUR, R. \& ZHANG, X. 2005. Fifty years of regional inequality in China: A journey through central planning, reform, and openness. Review of Development Economics, 9(1):87-106.

KUMAR, U. \& MISHRA, P. 2008. Trade liberalization and wage inequality: Evidence from India. Review of Development Economics, 12(2):291-311.

LU,M. \& CHEN,Z. 2004. Urbanization, urban-biased economic policies and urban-rural inequality.

Economic Research Journal, (06).

PERRY, G. \& OLARREAGA, M. 2006. Trade liberalisation, inequality and poverty reduction in Latin America. Mimeo, World Bank.

SHEN, Y. \& ZHANG, E. 2011. Foreign trade, FDI and urban-rural income gap. Forum of World Economics \& Politics, (06).

SHORROCKS, A.F. 1980. The class of additively decomposable inequality measures. Econometrica, 48(3):613-625.

WAN, G.H., LU, M. \& CHEN, Z. 2007. Globalization and regional income inequality: Empirical evidence from within China. Review of Income and Wealth, 53(1):35-59.

WANG, S. \& OUYANG, Z. 2007. The urban-rural income disparity and its effects to economic growth in the case of China. Economic Research Journal, (10).

WEI, H. \& LIU, Y. 2011. International trade and income inequality: Evidences from 125 countries. Statistical Research, (08). 
WEI, H. \& ZHAO, C. 2012. Effects of international trade on urban-rural income gap in China. Finance \& Trade Economics, (01).

WEI, H. 2009. Opening-up and regional income gaps in China: An empirical analysis based on the data from 1985 to 2007. World Economy Study, (11).

WEI, S.J. \& WU, Y. 2001. Globalization and inequality: Evidence from within China. NBER Working Paper, No. 8611.

YANG, J., SYLVIE, D. \& LI, S. 2011. Earnings differentials between the public and the private sectors in China. China Economic Quarterly, (01).

YUAN, D., WEI, H. \& YANG, H. 2011. Trade openness, improvement of trade commodity composition and urban-rural income inequality: An empirical study based on provincial panel data in China. China Soft Science, (06). 